\title{
Pendidikan Kesehatan Tentang Deteksi Dini Kanker Payudara Melalui Pemeriksaan Sadari (Periksa Payudara Sendiri) Di Pondok Pesantren Al-Hidayah dan Al- Maarif Kota Jambi
}

\author{
Ns Yusnilawati, Ns Indah Mawarti, Dini Rudini \\ FKIK Universitas Jambi
}

\begin{abstract}
Abstrak: Kematian akibat kanker payudara dapat mengalami penurunan dengan dilakukannya deteksi dini terutama pada usia remaja dengan melakukan pemeriksaan payudara sendiri. Tindakan ini sangat penting karena hampir $85 \%$ benjolan di payudara ditemukan oleh penderita sendiri. Pemeriksaan payudara sendiri (SADARI) dapat memperkecil angka kematian sampai 20\%, namun jumlah perempuan yang melakukan SADARI masih sedikit yaitu 25-30\%. Riset Penyakit Tidak Menular (PTM) tahun 2016 menyatakan perilaku masyarakat dalam deteksi dini kanker payudara masih rendah. Tercatat 53,7\% masyarakat tidak pernah melakukan SADARI, sementara 46,3\% pernah melakukan SADARI; dan 95,6\% masyarakat tidak pernah melakukan SADANIS, sementara $4,4 \%$ pernah melakukan SADANIS. Hal ini dilatarbelakangi oleh banyak nya remaja Indonesia yang belum mengetahui dan menyadari pentingnya SADARI untuk deteksi dini kanker payudara.

Metode : Mengikuti sosialisasi mengenai pentingnya deteksi dini kanker payudara melalui pemeriksaan "SADARI"(periksa payudara sendiri).Mengumpulkan para santriwati yang menjadi peserta pendidikan kesehatan. Mempersiapkan sarana dan prasarana kegiatan pendidikan kesehatan deteksi dini kanker payudara melalui pemeriksaan "SADARI"(periksa payudara sendiri), Mempersiapkan evaluasi dan monitoring secara bersama

Hasil : jumlah peserta di pondok pesantren Mambaul ulum lebih banyak dibandingkan Pesantren Al Maarif yaitu di pondok pesantren Mambaul Ulum sebanyak 125 orang $(80 \%)$ dan responden di Pondok Pesantren Al Maarif sebanyak 25 orang $(20 \%)$ ).Pendidikan kesehatan tentang deteksi dini kanker payudara melalui SADARI ini disampaikan oleh pihak puskesmas talang bakung yang menjadi wilayah kerja bagi lingkungan Pondok Pesantren. Setelah diberikan penyuluhan kemudian setiap peserta diberikan leafleat selaku responden yang berisikan materi tentang SADARI.

Kesimpulan: Penyuluhan kesehatan adalah salah satu bentuk promosi kesehatan yang sederhana dan dapat mencakup sasaran yang luas. Dari hasil penyuluhan kesehatan tentang "Deteksi dini kanker payudara melalui SADARI (Periksa payudara sendiri) yang telah dilakukan, dapat diambil kesimpulan bahwa siswi - siswi Pondok pesantren Mambaul Ulum dan Al Maarif dapat mengetahui tentang pentingnya pemeriksaan SADARI untuk deteksi dini kelainan pada payudara dan mencegah terjadinya kanker payudara serta bagaimana melakukan SADARI itu sendiri.
\end{abstract}

Kata Kunci : SADARI,

\section{PENDAHULUAN}

Berdasarkan data Global Burden Cancer (GLOBOCAN) pada tahun 2012 Kanker payudara merupakan penyakit kanker yang menempati urutan tertinggi didunia untuk kasus baru dengan presentase 43,3\% dan presentase kematian sebesar 12,9\% pada perempuan didunia. Pada tahun 2013 kanker payudara merupakan penyakit kanker dengan prevalensi tertinggi di Indonesia yaitu sebesar 0,5\%.

Kanker payudara adalah tumor ganas pada satu atau kedua payudara, kanker payudara juga merupakan benjolan atau massa tunggal yang sering terdapat di daerah kuadran atas bagian luar, benjolan ini keras dan bentuknya tidak beraturan dan tidak dapat digerakkan. Kanker payudara semakin banyak ditemukan pada usia muda, bahkan tidak sedikit remaja putri yang usia empat belas tahun menderita tumor dipayudaranya. Dimana tumor bisa menjadi kanker apabila tidak dideteksi sedini mungkin. Meskipun tidak semuanya ganas, tetapi ini menunjukan bahwa gejala kanker payudara yang semakin tinggi diusia remaja. 
Saat ini ada kecenderungan kanker payudara dialami oleh perempuan dengan usia (1520an), ini berarti tidak ada kata terlalu dini untuk memulai memberikan pendidikan SADARI secara rutin (7-10 hari setelah haid) setiap bulan. Insiden kanker payudara dan kematian yang diakibatkan oleh kanker payudara diseluruh dunia cenderung meningkat, hal ini disebabkan oleh keterlambatan pengobatan sehingga kanker payudara ditemukan pada stadium lanjut dan sulit diobati. Deteksi yang terlambat dan kurangnya informasi menyebabkan sebagian besar penderita kanker payudara terlambat diobati.

Masih sedikit nya penemuan kasus dalam stadium dini menyebabkan upaya deteksi dini menjadi sangat penting. Salah satu metode deteksi dini kanker payudara adalah pemeriksaan payudara sendiri (SADARI). SADARI atau pemeriksaan payudara sendiri merupakan pemeriksaan yang dapat dilakukan sendiri oleh wanita yang bertujuan untuk mengetahui ada tidaknya kanker dalam payudara. SADARI perlu dilakukan ketika seorang wanita telah mencapai masa pubertas dan mengalami perkembangan payudara. SADARI merupakan metode yang paling efektif dan efisien untuk menemukan kanker pada stadium dini.

Kematian akibat kanker payudara dapat mengalami penurunan dengan dilakukannya deteksi dini terutama pada usia remaja dengan melakukan pemeriksaan payudara sendiri. Tindakan ini sangat penting karena hampir $85 \%$ benjolan di payudara ditemukan oleh penderita sendiri. Pemeriksaan payudara sendiri (SADARI) dapat memperkecil angka kematian sampai 20\%, namun jumlah perempuan yang melakukan SADARI masih sedikit yaitu 25-30\%. Riset Penyakit Tidak Menular (PTM) tahun 2016 menyatakan perilaku masyarakat dalam deteksi dini kanker payudara masih rendah. Tercatat 53,7\% masyarakat tidak pernah melakukan SADARI, sementara 46,3\% pernah melakukan SADARI; dan 95,6\% masyarakat tidak pernah melakukan SADANIS, sementara 4,4\% pernah melakukan SADANIS. Hal ini dilatarbelakangi oleh banyak nya remaja Indonesia yang belum mengetahui dan menyadari pentingnya SADARI untuk deteksi dini kanker payudara.

\section{METODE PENELITIAN}

\subsection{Waktu dan lokasi kegiatan}

Kegiatan ini telah dilaksanakan pada tanggal 08 September 2018. Adapun lokasi kegiatan di Pondok pesantren Mambaul Ulum dan Pondok pesantren Al Maarif Kota Jambi

\subsection{Tahapan Pelaksanaan}

Adapun dalam kegiatan pengabdian masyarakat ini, tahapan pelaksanaannya sebagai berikut. 
Tabel 1. Tahapan pelaksanaan kegiatan pengabdian

\begin{tabular}{|c|c|c|c|}
\hline No & Tahapan & Metoda & Tempat \\
\hline 1 & $\begin{array}{l}\text { Memperoleh izin kegiatan dan sosialisasi } \\
\text { pendidikan kesehatan pada pihak pondok } \\
\text { pesantren (Kepala Sekolah) }\end{array}$ & $\begin{array}{l}\text { Ceramah, } \\
\text { diskuisi, } \\
\text { tanya jawab }\end{array}$ & $\begin{array}{l}\text { Pondok pesantren al- } \\
\text { hidayah dan al-maarif } \\
\text { Kota Jambi }\end{array}$ \\
\hline 2 & Mengidentifikasi santriwati calon peserta & Diskuisi & $\begin{array}{l}\text { Pondok pesantren al- } \\
\text { hidayah dan al-maarif } \\
\text { Kota Jambi }\end{array}$ \\
\hline 3 & $\begin{array}{l}\text { Pendidikan Kesehatan tentang deteksi dini } \\
\text { kanker payudara melalui pemeriksaan } \\
\text { "SADARI"(periksa payudara sendiri) }\end{array}$ & $\begin{array}{l}\text { Ceramah, } \\
\text { diskuisi, } \\
\text { Tanya jawab }\end{array}$ & $\begin{array}{l}\text { Pondok pesantren al- } \\
\text { hidayah dan al-maarif } \\
\text { Kota Jambi }\end{array}$ \\
\hline 4 & Evaluasi monitoring & $\begin{array}{l}\text { Sharing, } \\
\text { bimbingan }\end{array}$ & $\begin{array}{l}\text { Pondok pesantren al- } \\
\text { hidayah dan al-maarif } \\
\text { Kota Jambi }\end{array}$ \\
\hline
\end{tabular}

\subsection{Kontribusi Partisipan Mitra}

1. Mengikuti sosialisasi mengenai pentingnya deteksi dini kanker payudara melalui pemeriksaan "SADARI”(periksa payudara sendiri).

2. Mengumpulkan para santriwati yang menjadi peserta pendidikan kesehatan

3. Mempersiapkan sarana dan prasarana kegiatan pendidikan kesehatan deteksi dini kanker payudara melalui pemeriksaan "SADARI"(periksa payudara sendiri)

4. Mempersiapkan evaluasi dan monitoring secara bersama

\section{HASIL DAN PEMBAHASAN}

\subsection{Hasil Kegiatan}

Responden pada kegiatan pendidikan kesehatan ini adalah siswi di Pondok pesantren Mambaul Ulum dan Pondok pesantren Al Maarif, dimana jumlah respondennya kurang lebih 150 peserta.

Tabel 2. Distribusi frekuensi berdasarkan jumlah peserta

\begin{tabular}{ccc}
\hline Pondok Pesantren & Jumlah Peserta & Persentase \\
\hline Mambaul Ulum & 125 orang & $80 \%$ \\
Al Maarif & 25 orang & $20 \%$ \\
\hline
\end{tabular}

Berdasarkan tabel 5.1 diatas dapat diketahui bahwa jumlah peserta di pondok pesantren Mambaul ulum lebih banyak dibandingkan Pesantren Al Maarif yaitu di pondok pesantren Mambaul Ulum sebanyak 125 orang (80 \%) dan responden di Pondok Pesantren Al Maarif sebanyak 25 orang $(20 \%)$.

Pendidikan kesehatan tentang deteksi dini kanker payudara melalui SADARI ini disampaikan oleh pihak puskesmas talang bakung yang menjadi wilayah kerja bagi lingkungan Pondok Pesantren. Setelah diberikan penyuluhan kemudian setiap peserta diberikan leafleat selaku responden yang berisikan materi tentang SADARI 


\subsection{Luaran yang dicapai}

Luaran yang dicapai dari kegiatan pengabdian ini adalah berupa draf artikel yang akan dipublikasikan di jurnal nasional terakreditasi, menghasilkan kegiatan penelitian yang akan dilaksanakan di lingkungan FKIK UNJA dan juga sebagai informasi tambahan terhadap deteksi dini kanker payudara melalui SADARI

\section{KESIMPULAN DAN SARAN 4.1. Kesimpulan}

Penyuluhan kesehatan adalah salah satu bentuk promosi kesehatan yang sederhana dan dapat mencakup sasaran yang luas. Dari hasil penyuluhan kesehatan tentang "Deteksi dini kanker payudara melalui SADARI (Periksa payudara sendiri) yang telah dilakukan, dapat diambil kesimpulan bahwa siswi-siswi Pondok pesantren Mambaul Ulum dan Al Maarif dapat mengetahui tentang pentingnya pemeriksaan SADARI untuk deteksi dini kelainan pada payudara dan mencegah terjadinya kanker payudara serta bagaimana melakukan SADARI itu sendiri.

\subsection{Saran}

Pendidikan kesehatan pada remaja putri sebaiknya dilakukan secara berkesinambungan dengan berbagai masalah kesehatan terutama pada penyakit-penyakit yang bersifat mematikan seperti kanker payudara, kanker serviks dll. Untuk itu perlu adanya kerjasama yang baik antara pemerintah, dinas kesehatan kota dengan sekolah-sekolah di lingkungan Kota Jambi untuk menjalankan program pendidikan kesehatan agar dapat berjalan dengan baik dan optimal.

\section{DAFTAR PUSTAKA}

American Cancer Society. (2016). Cancer Facts and Figures 2016. Atlanta, Ga: American Cancer Society

Kemenkes RI. (2015). Pusat Data dan Informasi (InfoDATIN) Kementrian Kesehatan RI. Jakarta Selatan

Harnianti, Harnianti, and Syawal Saptaputra. "Studi Perilaku Pemeriksaan Payudara Sendiri (SADARI) Pada Mahasiswi Fakultas Kesehatan Masyarakat Universitas Halu Oleo Tahun 2016." Jurnal Ilmiah Mahasiswa Kesehatan Masyarakat 1.3 (2017).

Alfiksa, Annisa Eka Nur, and Hikmah Hikmah. Pengaruh Penyuluhan Tentang Pemeriksaan Payudara Sendiri (Sadari) Terhadap Sikap Remaja Putri di SMA Islam 1 Gamping Yogyakarta tahun 2012.Diss. STIKES'Aisyiyah Yogyakarta, 2015.

Available from: http://jurnal.unimus.ac.id/index.php/jur_bid/article/view/551/601

Availablefrom: http://www.mediaindonesia.com/news/read/123340/deteksi-kanker-payudaraterabaikan/2017-09-20 